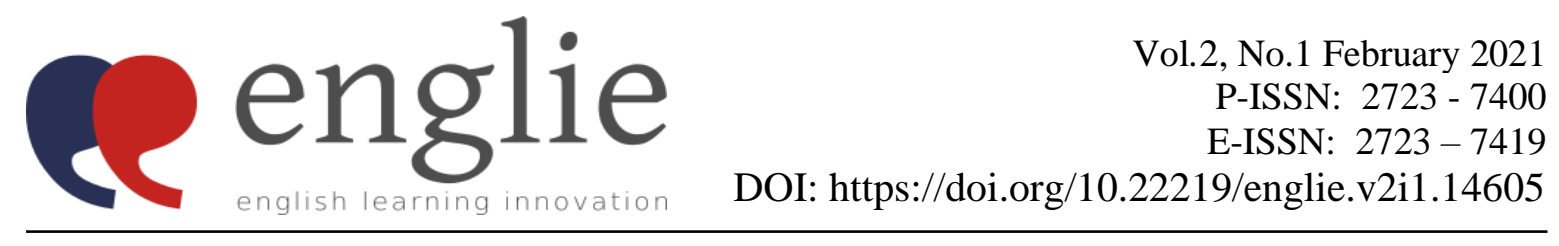

\title{
Improving the Students' Motivation in Learning English through Google Meet during the Online Learning
}

\author{
Rizal Wahid Permana Putra
}

SMP Negeri Satu Atap Jarit, East Java, Indonesia

Corresponding Author: rizalwpermana@gmail.com

\begin{abstract}
Due to the Covid-19 outbreak, it has profoundly changed our education system. This condition has led the teachers to alter the face-to-face learning into online learning. Online learning emphasizes on the internet-based courses synchronously and asynchronously. Besides its technical problems, conducting online learning was said to be monotonous since the teachers preferred doing online tasking to providing effective learning experience. Further, this condition led to low students' motivation in learning English. In other words, the students might be in boredom to participate and engage in the teaching- learning process owing to the monotonous learning. Some students were found late or even reluctant to complete the assignments. Therefore, the researcher conducted the Classroom Action Research (CAR) dealing with the use of Google Meet (GM) to improve the students' motivation in learning English during the online learning. The research subject was the $7^{\text {th }}$ grade students of SMP Negeri Satu Atap Jarit. The research was conducted in two cycles. In cycle I, it showed that there was an increase of students' motivation in learning English. The increase of students' motivation was $61,8 \%$. Surprisingly, in cycle II, the researcher found that the Google meet significantly improved the students' motivation up to $79,4 \%$. The result showed that the students actively participate and engage in the teaching-learning process. Due to the GM application, the students were very enthusiastic to respond and answer the some questions, and share their ideas related to the topic of the meeting. In addition, the increase of students' motivation influenced student development to compose sentences correctly related to the given assignments. Based on the result of data analysis, the researcher drew a conclusion that the use of GM could significantly affect students' motivation in learning English during the virtual learning.
\end{abstract}

Keywords: Google meet, Learning English, Students' Motivation

\section{INTRODUCTION}

The Covid-19 outbreak has changed various fields, including our education system. This condition has led the teachers to shift the direct classroom instruction into virtual one. Online learning is the newest and most popular form of distance education today (Stern, 2019). Currently, it becomes the most used teaching approach due to practicality aspect in this pandemic situation. Online learning emphasizes on the internet-based courses synchronously and asynchronously (Lin \& Gao, 2020). However, conducting online learning for the English learning could be a challenge for English as a Foreign Language Teacher (EFL) teachers. Some 
issues include the availability of facilities, infrastructures, bad signals etc. Students commonly have the same problems, particularly, their internet data.

During the Covid-19 pandemic, delivering the material could be a real problem for EFL teachers. This condition occurred since the transition of instructional method from face-to-face to online learning has forced the English teachers to give more exercises rather than to teach the students (Hamilton, 2010). Ybarra \& Green (2003) stated the process of learning a new language can be boring and painful for students, so they need much language support and the teachers who teach English know that any language support is helpful for language acquisition. So, the teachers' attendance is highly required to ensure the English acquisition. Otherwise, it would be really hard for EFL students to get to know the new language or English better considering this language is a foreign language. So, it the English learning activities were merely asking the students to submit the assignment, it would be said that they have lack of understanding of the language. This situation led into students' low motivation to learn English (Damayanti, 2017)

Additionally, students were often late or even reluctant in collecting and completing some assignments given by the teachers since most of them do not really understand about what they need to do with the assignment, and have lack of knowledge the materials related to the assignment. This situation could be worse if the teachers keep asking the students to do the same thing again and again (Lathipatud Durriyah \& Zuhdi, 2018).

When implementing the online learning, most English teachers were not able to use various media or platforms as well as learning activities in online learning. Lee \& Drajati, (2019) said their digital literacy make could be the cause it that situation. The process of teaching and learning tended to be monotonous (Lathipatud Durriyah \& Zuhdi, 2018). Thus, it led to the students' boredom. As a consequence, this situation significantly affected the students' motivation in learning English during the pandemic. The students' low learning motivation could be indicated through their attendance list and participation during the class on WhatsApp. Moreover, the decrease of students' EFL learning motivation might lead to the decrease of their achievement owing to monotonous learning and having unable to understand the subject matter well. In several cases that the researcher found in the school, there were only 6 to 7 of 13 students joined the online classroom using WhatsApp. The long run of this condition can trigger to students' fear when dealing with English. This condition can't be taken for granted if English teachers put high expectation towards better English mastery for Indonesian learners (Hidayati, 2016).

In short, considering the low motivation of the students in learning English when the teaching approach is monotonous, keeping asking the students to submit the assignment online. Some studies showed that the use of virtual class using video conferences such as Google Meet can raise the students to learn English. Miftah (2018) found the use of PowerPoint presentation are obviously effective to improve the students' motivation in learning English when used in online class. The result showed that power point used by the teacher could motivate the students in learning, keep the students' attention, and engage the students' participation and concentration. He found it in his Classroom Action Research (CAR). To dig deeper result, the researcher attempted to identify through CAR focusing on the use of GM as the media to improve the $7^{\text {th }}$ grade students' motivation in learning English during online learning.

\section{METHOD}

This research is CAR to investigate the use of GM in improving the students' motivation in learning English. Latief (2012) highlighted Classroom Action Research is an effective way to improve both the English teachers' quality in term of performance and students' achievement in learning English. Therefore, this type of research is highly recommended for teachers to identify the class strengths and weaknesses which is expected to boost the students learning 
performance. Also, this Classroom Action Research, it is expected to solve the problem and improve the students' motivation in learning English.

This Classroom Action Research was conducted at SMP Negeri Satu Atap Jarit, in the first semester of 2020/2021 for 3 months, starting from September to November 2020. This CAR was conducted using a different approach, that is online learning as part of the government stipulation to eliminate the Covid-19 spread. Meanwhile, the research subjects of this research was $7^{\text {th }}$ grade students of SMP Negeri Satu Atap Jarit with the total of 13 students, consisting of 5 female and 8 male students in a class.

This CAR implementation was divided into two cycles as a part to obtain the data. Kemmis \& Taggart (1998) stated Action Research involves cycles, consisting of 4 stages: Planning, Acting, Observing, and Reflecting. Planning referred to the phase to design interactive learning as well as the lesson plan, and select the related topic to teach. Acting was carried out to implement designed-interactive learning, lesson plan, and the media to teachinglearning process. Observing was the phase to observe the activities during acting phase using prepared observation sheet. Further, reflecting was done to evaluate the acting done in each cycles whether or not the results meet the criteria of success. Meanwhile, in collecting the data, the researcher used observation and the assignment. In addition, to be able to identify students' motivation, the assignment was given as an approach to know whether the increase of students' motivation in learning English occurred or not.

\section{FINDINGS AND DISCUSSION}

Before conducting the cycle 1 to improve the students' motivation in learning English, the researcher conducted preliminary observation and pre-assignment. The result of the preliminary observation was showcased in table 1 below.

Table 1. Preliminary observation

\begin{tabular}{clcc}
\hline \multirow{2}{*}{ No } & \multicolumn{3}{c}{ Preliminary Observation } \\
\cline { 2 - 4 } & Aspects & Frequency & Percentage \\
\hline 1 & Willingness to learn & 7 & $53,8 \%$ \\
\hline 2 & Collecting and completing assignments & 5 & $38,4 \%$ \\
\hline 3 & Learning discipline & 6 & $46,1 \%$ \\
\hline 4 & Stating the ideas & 5 & $38,4 \%$ \\
\hline 5 & Composing sentences & 5 & $38,4 \%$ \\
\hline \multicolumn{2}{c}{ The average }
\end{tabular}

From the preliminary observation and pre-assignment, the result showed that the students' motivation was considered low. It was identifiable through the average students' score 43, 3\%. It means students were reluctant to develop their English.

This data was as the base to know further about the student motivation after the treatment. After obtaining the data form preliminary observation and pre-assignment, the researcher then conducted the cycle 1 .

\section{The Implementation of Cycle I}

Cycle I involved one meeting. The first meeting held on Tuesday, September $22^{\text {nd }} 2020$, the researcher carried out the Track Changes, involving four stages; plan, action, observation, and reflection.

\section{Plan}

To ease the action stage, the researcher carried out some preparation as follows: designing the lesson plan, media (Google sites), and students' worksheet (LKPD).

\section{Action}


In action and observation stage, the researcher was as the teacher and observer. This stage was aimed at implementing the chosen strategy in teaching-learning process. The teacher commenced the Cycle I in teaching-learning process synchronously through the use of Google Meet. The synchronous-learning process was carried out for 5 to 10 minutes. During the synchronous learning, the teacher showed and explained the materials on the Google sites to the students through GM. In addition, in the end of the learning, the researcher provided the students an assignment related to the subject matter.

\section{Observation}

During the implementation of Cycle I, the researcher was also the classroom teacher as well as the observer. Based on the result of observation, the researcher found there was an increase of students' motivation in learning English. The researcher/ observer actively participated and engaged in the teaching-learning process. The researcher identified students' active participation seen through the attendance during the lesson. The increase of students' motivation was presented in the table 2 as follows:

Table 2. The Observation of Cycle I

\begin{tabular}{clcc}
\hline \multirow{2}{*}{ No } & \multicolumn{3}{c}{ Table 2. The Observation of Cycle I } \\
\cline { 2 - 4 } & \multicolumn{1}{c}{ Aspects } & Frequency & Percentage \\
\hline 1 & Willingness to learn & 9 & $69,2 \%$ \\
\hline 2 & Collecting and completing assignments & $61,5 \%$ \\
\hline 3 & Learning discipline & 9 & $69,2 \%$ \\
\hline 4 & Stating the ideas & 6 & $46,1 \%$ \\
\hline 5 & Composing sentences & 7 & $63,8 \%$ \\
\hline \multicolumn{2}{c}{ The average }
\end{tabular}

Based on the result of data analysis, there was an increase of students' motivation in learning English. The researcher found that the increase of students' motivation in learning English was quite significance $(61,8 \%)$ during and after conducting the Cycle I.

\section{Reflection}

After conducting the steps of cycle 1: plan, action, and observation, the researcher did the reflection stage. In this reflection stage, the researcher analyzed the result of observation and drew a conclusion as well as provided positive feedback to the teaching-learning process. The result showed that there was a significant increase of students' motivation in learning English through the GM conducted by the teacher. The students were responsive engaged to share their ideas and answer some triggered questions from the teacher. However, the researcher found there were some problems during the implementation of Cycle I. Those included 9 students who joined the class, only 8 students collect and complete the assignment, 6 students state ideas, and 7 students compose a simple sentence well. Those, in fact, are far better approach of online teaching, so it clearly indicated that GM is an applicable option for digital learning.

Upon completing the reflection of Cycle I, the researcher got started to begin Cycle II to know further the impact of GM to facilitate and assist the student advancement in teaching-learning process. 


\section{The Implementation of Cycle II}

Cycle II involved one meeting. The first meeting held on Tuesday, October $20^{\text {th }} 2020$, the researcher carried out the Track Changes, involving four stages; plan, action, observation, and reflection.

\section{Plan}

In plan stage of Cycle II. The researcher varied the preparation as follows: designing the lesson plan and learning activities, providing media (Google sites and PPT), and students' worksheet (LKPD).

\section{Action}

During this stage, the researcher acted as the teacher as well as the observer in the teaching and learning process. The implementation of action stage in Cycle II differed from the Cycle II. The researcher started the Cycle II in teaching and learning process synchronously through the Google Meet. The synchronous activities were held two times. The first synchronous activity was the opening classroom through GM. In this first synchronous activity, the researcher instructed the students to read and learn the material on Google Sites asynchronously. Then, the students should be back on GM in 5 to 10 minutes.

After the students learning and reading the material on Google Sites asynchronously, the second synchronous-learning process was carried out by the researcher. In this second synchronous-learning process, the researcher commenced the classroom lesson by asking some triggered questions related to the material. Then, during the second synchronous learning, the researcher explained the material through Google Meet. Here, the material was conveyed synchronously through GM using the PowerPoint in 5 to 10 minutes. At the end of the lesson, the researcher provided the students an assignment.

\section{Observation}

Based on the result of observation carried out in Cycle II, the students' motivation in learning English rose. The escalation of students' motivation was identifiable from the students' attendance during the class, students' participation during the learning, students' willingness to collect and completing the assignment, and the average score in composing a simple sentence. In addition, the proliferation of students' motivation was presented in the table 3 below.

Table 3. The Observation of Cycle II

\begin{tabular}{clcc}
\hline \multirow{2}{*}{ No } & \multicolumn{3}{c}{ Table 3. The Observation of Cycle II } \\
\cline { 2 - 4 } & \multicolumn{1}{c}{ Aspects } & Frequency & Percentage \\
\hline 1 & Willingness to learn & 11 & $84,6 \%$ \\
\hline 2 & Collecting and completing assignments & 11 & $84,6 \%$ \\
\hline 3 & Learning discipline & 11 & $84,6 \%$ \\
\hline 4 & Stating the ideas & 9 & $69,3 \%$ \\
\hline 5 & Composing sentences & 10 & $76,9 \%$ \\
\hline \multicolumn{2}{c}{ The average }
\end{tabular}

The result showed that the students' motivation was better than in Cycle I. There was an increase of students' motivation in learning English. The increase of students' motivation was $79,4 \%$. It was considered as a good improvement after conducting the Cycle II.

\section{Reflection}

At the end of the Cycle II, the researcher did the reflection stage to analyze and evaluate the process of Cycle II. In this reflection stage, the researcher drew a conclusion and provided positive feedback to the learning carried out in Cycle II. Based on the Cycle II, the students' motivation in learning English escalated when GM was implemented as a part of the classroom 
instruction. Here, the GM use was intertwined with the various activities and media. The increase of students' motivation was $79,4 \%$.

From the data of observation, 11 students showed their willingness to learn, to collect and complete the assignment, and showed their discipline during the teaching-learning process. The increase was clearly seen from the number of students who was willing to share their ideas and compose a simple sentence well. It showed that 9 students were able to share their ideas during the lesson, and 10 students were able to compose a simple sentence well. In short, from the result of data analysis and reflection, the researcher drew a conclusion that the students' motivation in learning English through GM was convincingly accelerating.

\section{DISCUSSION}

In this research, the Classroom Action Research was carried out in two cycles. During the teaching-learning process in each cycles, the researcher chose the related topics to learn. The topics taught were related topic in KD 3.2 and 4.2. The related topics were chosen to prepare the students for the mid-term examination.

In collecting the data to investigate the students' motivation in learning English during the implementation Cycle I and II, the researcher implemented the observation sheets and assignment. The observation sheet was adjusted with the 5 aspects found during the teachinglearning process. Those 5 aspects were students' willingness to learn, students willingness to collect and complete the assignment, their' discipline during the lesson, students' ways to share their ideas, and students' competence to compose the simple sentence.

In this Classroom Action Research, the researcher applied GM as an approach of virtual teaching and learning process to improve the students' motivation in learning English. This approach was expected to improve the students' motivation in learning English during the pandemic situation. Before conducting the research, the researcher found that the students' motivation to learn English was categorized as low. From the preliminary observation and preassignment, the result showed that the average of students' motivation was 33, 3\%. This condition was pondered due to monotonous teaching and learning process and the teachers' tendency to just supply the students with some assignments without any proper guidance from them (Alhaisoni \& Rahman, 2013).

In Cycle I, the treatment was done by the researcher to improve the students' motivation in learning English. The treatment was the use of GM as the teaching approach when instruction the students in class. The result of data analysis after conducting the Cycle I, showed that there was significant improvement of students' motivation in learning English. It clearly indicated that the use of online platform can boost the EFL students motivation to increase their English skills (Erarslan, 2019). In addition, the students' motivation in learning English were seen from 5 aspects: 9 students were actively participating in EFL learning, 8 students collected and completed the assignment, 9 students were disciplined to join the class, 6 students were brave to share their ideas, and 7 students were able to compose a simple sentences related to the given assignment. In short, based on the result of the data analysis, the growth of students' motivation in learning English was 61,8\%, and it was considered to be better than before conducting the Cycle I in teaching and learning process.

To obtain more convincing data using GM as a part of the classroom approach to accelerate the students' motivation in learning English, the researcher then conducted the Cycle II. The researcher began to design the treatment of Cycle II through the GM approach with the various learning activities and media.

During the observation, the researcher found that there were an advancement of students' willingness to learn. Based on the result of the data analysis, the researcher found that the 
students' motivation in learning English experience an increase. The increases of students' motivation were showed as follows: the students' willingness to learn was $84 \%$, students' eager to collect and complete the assignment was $84 \%$, students' discipline was $84 \%, 69,3 \%$ of students' were sharing their ideas, and $76,9 \%$ of students were able to compose a simple sentence related to the assignment correctly. Al in all, the average of students' motivation in learning English was 79, 4\%.

Based on the result of data analysis after conducting the Cycle I and II, the researcher found that the use of GM in teaching and learning process was able to improve the students' motivation in learning English. Therefore, the researcher suggested English teachers to vary their classroom teaching by having various approaches; giving assignments, using GM synchronously and asynchronously and texting via WhatsApp as part of the communication. GM is quite effective to enhance learners' English competence and motivation. The materials for online learning (GM) should be easily accessed by the students (Nartiningrum, 2020). The students' motivation in learning English is shown by the students' participation during the class, the students' responds to the questions, the students' willingness to share their ideas, and the students' ability to compose a simple sentence correctly related to the requested assignment. During conducting Cycle I and II, the students were actively and eagerly involved in the learning activities provided by the teacher. In addition, the students were very enthusiastic to join and engage in GM. As result, they will become more autonomous learners (Zainuddin \& Perera, 2019)

\section{CONCLUSION}

This Classroom Action Research was conducted on the $7^{\text {th }}$ grade students due to the issues of low motivation. Based on the preliminary observation during online learning, the researcher found students' low motivation because online class was dominated by assignments.

Based on the result of research findings, the researcher draws conclusion that using the GM on online-teaching-learning process can improve the students' motivation in learning English. After conducting the Cycle I and II, the students' motivation in learning English significantly increased. The increase can be proven from the number of students joining the class during the online learning via GM. The language input delivered via GM was the trigger of their motivation (Nugroho et al., 2020). Furthermore, during the GM session, the students actively participated and was engaged in teaching-learning process. The students were very enthusiastic to respond and answer some triggered questions from the teacher, and share their ideas during the lesson. In addition, this students' motivation positively influenced their average score in composing a simple sentence. So, the researcher would keep doing this type of teaching approach in the future. Also, this approach might be applicable for other English teachers in the other schools

\section{ACKNOWLEDGMENT}

The author thanks to the Principal of SMP Negeri Satu Atap Jarit, the teachers of SMP Negeri Satu Atap Jarit, and the $7^{\text {th }}$ grade students of SMP Negeri Satu Atap Jarit for peerless support to conduct the Classroom Action Research with the specified schedule and condition. This research was conducted as the reference to the English teacher of SMP Negeri Satu Atap Jarit to solve the problems and improve the students' motivation in learning English during the online learning (Belajar Dari Rumah) academic year 2020/2021. 


\section{REFERENCES}

Alhaisoni, E., \& Rahman, M. M. U. (2013). Teaching English in Saudi Arabia: Prospects and Challenges. Academic Research International, 4(1), 112-118.

Damayanti, I. L. (2017). From storytelling to story writing: The implementation of reading to learn (R2L) pedagogy to teach english as a foreign language in Indonesia. Indonesian Journal of Applied Linguistics, 6(2), 232-245. https://doi.org/10.17509/ijal.v6i2.4870

Erarslan, A. (2019). Instagram as an Education Platform for EFL Learners. Turkish Online Journal of Educational Technology - TOJET, 18(3), 54-69.

Hamilton, R. (2010). YouTube For Two: Online Video Resources. Contemporary Issues In Education Research, 3(8), 27-32.

Hidayati, T. (2016). Integrating ICT in English language teaching and learning in Indonesia. JEELS (Journal of English Education and Linguistics Studies), 3(1), 38-62.

Kemmis, S., \& Taggart, M. (1998). The Action Research Planner (3rd Editon). Deakin University.

Lathipatud Durriyah, T., \& Zuhdi, M. (2018). Digital Literacy With EFL Student Teachers: Exploring Indonesian Student Teachers' Initial Perception About Integrating Digital Technologies Into a Teaching Unit. International Journal of Education and Literacy Studies, 6(3), 53. https://doi.org/10.7575/aiac.ijels.v.6n.3p.53

Latief, M. A. (2012). Research methods on language learning: An introduction. Malang: UM Press.

Lee, J. S., \& Drajati, N. A. (2019). English as an international language beyond the ELT classroom. ELT Journal, 73(4), 419-427. https://doi.org/10.1093/elt/ccz018

Lin, X., \& Gao, L. (2020). Students' sense of community and perspectives of taking synchronous and asynchronous online courses. Asian Journal of Distance Education, 15(1), 2020. http://www.asianjde.org

Miftah. (2018). The Use of Power Point Presentation to Improve Students' Motivation in Learning English. English Language Journal, 3(2), 5-12.

Nartiningrum, N. (2020). Online learning amidst global pandemic: EFL students' challenges, suggestions, and needed materials. Academic Journal of English Language and Education, 4(2), 115-140.

Nugroho, A., Zamzami, M. R. A., \& Ukhrowiyah, N. F. (2020). Language input, learning environment, and motivation of a successful EFL learner. Journal on English as a Foreign Language, 10(1), 46-69. https://doi.org/10.23971/jefl.v10i1.1511

Stern, J. (2019). Introduction to online teaching and learning. http://www.wlac.edu/online/documents/otl.pdf

Ybarra, R., \& Green, T. (2003). Using technology to help ESL/EFL students develop language skills. The Internet TESL Journal, 9(3), 1-5.

Zainuddin, Z., \& Perera, C. J. (2019). Exploring students' competence, autonomy and relatedness in the flipped classroom pedagogical model. Journal of Further and Higher Education, 43(1), 115-126. https://doi.org/10.1080/0309877X.2017.1356916 